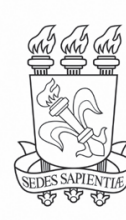

\title{
Artigos
}

\section{Morphophysiological responses of Hymenaea stigonocarpa Mart. ex Hayne seedlings submitted to potassium fertilization}

\begin{abstract}
Resposta morfofisiológica de mudas de Hymenaea stigonocarpa Mart. ex Hayne submetidas à adubação potássica
\end{abstract}

\author{
Andréia Mendes da Costa ${ }^{\oplus}$ \\ Leandro Carlos ${ }^{\circledR}$ \\ Patrícia Oliveira da Silva ${ }^{\oplus}$ \\ Paulo Eduardo Menezes-Silva' ${ }^{\odot}$ \\ José Milton Alves ${ }^{\oplus}$ \\ Thomas Jefferson Cavalcante ${ }^{\oplus}$ \\ Jorciane Souza Dias ${ }^{\oplus}$ \\ Instituto Federal Goiano, Rio Verde, GO, Brazil
}

\begin{abstract}
Hymenaea stigonocarpa is anarboreal medicinal species used in the recovery of degraded areas. However, little is known about its nutritional requirements during the seedling phase, especially concerning to potassium. In this context, the aim of this study was to evaluate if potassium doses promote morphophysiological changes in Hymenaea stigonocarpa seedlings. A completely randomized design, consisting in six $\mathrm{KCl}$ doses $(0,50,100,150,200$ and $250 \mathrm{mg}$ $\mathrm{dm}^{-3} \mathrm{KCl}$ ) and four replications was applied. Biometric, biomass, physiological and potassium content variables were assessed. Hymenaea stigonocarpa displayed significant physiological and biometric responses to potassium fertilization, with the highest values observed at doses ranging from 150 to $200 \mathrm{mg} \mathrm{dm}^{-3} \mathrm{KCl}$. Moreover, concentration effects were noted regarding to potassium contents in seedling leaves and stems.
\end{abstract}

Keywords: K; Early phase; Physiology; Growth; Jatobá-do-Cerrado 


\section{RESUMO}

Hymenaea stigonocarpa é uma espécie arbórea medicinal usada na recuperação de áreas degradadas. No entanto, pouco se sabe sobre suas exigências nutricionais durante a fase de mudas, principalmente em termos de potássio. Dessa forma, objetivou-se com este trabalho avaliar se doses potássicas promovem alterações morfofisiológicas de mudas Hymenaea stigonocarpa. O delineamento utilizado foi inteiramente ao acaso, com seis doses $(0,50,100$, 150, 200 e $250 \mathrm{mg} \mathrm{dm}^{-3} \mathrm{de} \mathrm{KCl}$ ), e quatro repetições. As variáveis avaliadas foram: biométricas, biomassa, fisiológicas e teor de potássio. A espécie apresentou resposta significativa à adubação potássica para os parâmetros fisiológicos e biométricos. Os maiores valores obtidos foram nas doses entre 150 e $200 \mathrm{mg} \mathrm{dm}^{-3}$. E, ainda, observou-se efeito de concentração para o teor de potássio contido nas folhas e caule das mudas de Hymenaea stigonocarpa.

Palavras-chave: K; Fase inicial; Fisiologia; Crescimento; Jatobá-do-Cerrado

\section{INTRODUCTION}

The interest in the use of native Cerrado species for the conservation and recovery of degraded areas has increased in the last years due to the need for ecosystem preservation (OLIVEIRA, 2019). The increasing degradation noted in this biome is due to the consequences of disordered growth in the Brazilian savannas, resulting from the rapid expansion of agriculture and livestock (SILVA; SOUZA; FURTADO, 2013), leading to deforestation, vegetation burning, land use conversion and consequent pollution of aquifers and soils, thus causing a series of environmental imbalances (GOMES; MIRANDA; BUSTAMANTE, 2018; GRANATO-SOUZA; BARBOSA; CHAVES, 2019). In response to these changes, many species in this domain have been compromised, including Hymenaea stigonocarpa. In this scenario, the maintenance of both native vegetation and Hymenaea stigonocarpa may be carried out through the seedling production and planting in areas subject to recovery.

Jatobá-do-Cerrado (Hymenaea stigonocarpa Mart. Ex Hayne) is an endemic tree species belonging to the Fabaceae family. Its seeds display a cutaneous dormancy that hinders and slows germination, leading to slow vegetative growth, classified as climax (COSTA et al., 2015), which makes natural reproduction difficult. It is indicated in the recovery of degraded areas, while also displaying the potential to be used as a food item. In addition, it is also medicinal, as it presents antifungal and antimicrobial 
activity, and is recommended in the treatment of bacterial infections, inflammatory processes, rheumatism and anemia (SILVA et al., 2020). The species is also economically important, due to its use in the timber industry, although it has often been subjected to illegal logging in the recent decades, compromising its local density (GRANATOSOUZA; BARBOSA; CHAVES, 2019).

However, the Cerrado biome is a stressful environment, comprising savanna formation, and frequently long drought periods, and local species are thus subject to water deficit and low nutritional availability, limiting growth during the early development stages (COSTA et al., 2015). One of the strategies utilized by plants to circumvent the stress imposed by the local climate is the use of certain nutrients in the enhancement of defense mechanisms, such as potassium (K) (BATTIE-LACLAU et al., 2014), due to its osmotic adjustment function. However, no studies evidencing the effects of potassium fertilization on Hymenaea stigonocarpa seedling production are available to date.

Among the most widely applied commercial fertilizers as a potassium plant source is potassium chloride $(\mathrm{KCl})$. This compound increases potassium $\left(\mathrm{K}^{+}\right)$and chlorine $(\mathrm{Cl})$ ions in the soil, which are essential in controlling stomatal opening and closing. These responses are due to the fact that plants receiving adequate $\mathrm{K}^{+}$levels display a significant ability to regulate the carbon and nitrogen metabolism, since photosynthetic rates are one of the most affected processes by potassium fertilization (ZAHOOR et al., 2017). In addition, $\mathrm{Cl}$ is associated with gas exchange measurements and participates in an acyclic movement (non-acyclic phosphorylation) in the electrochemical transport rate (ETR) photochemical step, obtained through the photo-oxidation of water $\left(\mathrm{O}_{2}\right)$ in the photosystem II (TAIZ; ZEIGER, 2017).

In this context, the hypothesis that increasing potassium levels in soil improve the ability of Hymenaea stigonocarpa seedlings to improve morphological and physiological responses was tested herein. Given the above, the aim of this study was to evaluate if potassium fertilization promotes morphophysiological and potassium content changes in Hymenaea stigonocarpa Mart. ex Hayne seedlings submitted to different potassium doses. 


\section{MATERIAL AND METHODS}

The experiment was conducted in a greenhouse at Goiano Federal Institute - Rio Verde Campus, between September 2016 and May 2017. The soil used to conduct the experiment according to FAO is classified as Dystrophic Red Latosol and was obtained from a Native Forest area $\left(17^{\circ} 47^{\prime} \mathrm{S}\right.$ e $\left.50^{\circ} 54^{\prime} \mathrm{W}\right)$. After sampling, the physicochemical soil composition under natural conditions was characterized at a depth of 0-20 cm collected from horizon " $\mathrm{A}$ " of the soil profile containing the highest organic matter contents (Table 1). The soil was previously sieved and fertilized according to the physicochemical soil analyses Raij (1981).

Table 1 - Dystrophic Red Latosol physicochemical characterization in its natural condition

\begin{tabular}{|c|c|c|c|c|c|c|c|c|c|c|c|c|}
\hline $\mathrm{Ca}$ & Mg & Al & $\mathrm{H}+\mathrm{Al}$ & CTC & OM & $\mathbf{m}$ & v & $\mathrm{K} / \mathrm{CEC}$ & $\mathrm{Ca} / \mathrm{CEC}$ & $\mathrm{Mg} / \mathrm{CEC}$ & \multicolumn{2}{|c|}{$\mathrm{H}+\mathrm{Al} / \mathrm{CEC}$} \\
\hline \multicolumn{5}{|c|}{$\mathrm{cmolc} \mathrm{dm}^{3}$} & \multicolumn{8}{|c|}{$\%$} \\
\hline 0.4 & 0.1 & 0.30 & 4.5 & 5.11 & 2.7 & 33 & 12 & 2.2 & 7.8 & 2.0 & \multicolumn{2}{|c|}{88.2} \\
\hline$K$ & $\mathbf{P}$ & $S$ & $\mathrm{Na}$ & B & $\mathrm{Cu}$ & $\mathrm{Fe}$ & $M n$ & $\mathrm{Zn}$ & $\mathrm{pH}$ & Clay & Sand & Silt \\
\hline \multicolumn{9}{|c|}{$\mathrm{mg} / \mathrm{dm}^{3}$} & $\mathrm{CaCl}_{2}$ & \multicolumn{3}{|c|}{$\%$} \\
\hline 44 & 1 & 6 & 1 & 0.2 & 33.9 & 26 & 18 & 0.2 & 4.30 & 50 & 32 & 18 \\
\hline
\end{tabular}

Source: Authors (2021)

In where: Ca: calcium; Mg: magnesium; Al: aluminum; $\mathrm{H}+\mathrm{Al}$ : hydrogen plus aluminum; CEC: cation exchange capacity; OM (\%): organic matter; $M(\%)$ : aluminum saturation; $V(\%)$ : base saturation; CEC saturation with $\mathrm{K}(\mathrm{K}: \mathrm{CEC})$; $\mathrm{Ca}(\mathrm{Ca}: \mathrm{CEC}), \mathrm{Mg}$ (Mg: $\mathrm{CEC}$ ) and $\mathrm{H}+\mathrm{Al}(\mathrm{H}+\mathrm{Al}: \mathrm{CEC})$; $\mathrm{K}$ : potassium; P: phosphorus; S: sulfur; Na: sodium; B: boron; Cu: copper; Fe: iron Mn: manganese and Zn: zinc.

The experiment consisted of six potassium doses $(0,50,100,150,200$ and 250

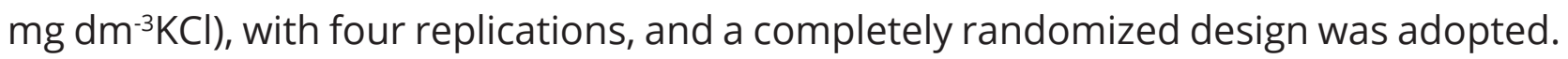
The soil correction followed the methodology proposed by Raij (1981) to raise base saturation to $60 \%$, followed by incubation for 20 days. Calcium carbonate $\left(\mathrm{CaCO}_{3}\right.$ P.A.) and magnesium carbonate $\left(\mathrm{MgCO}_{3}\right.$ P.A.) were used as corrective agents at a 4:1 ratio, considering the optimal potassium absorption range.

Basic fertilization was applied to all experimental units, applying the 
following doses and fertilizers: $40 \mathrm{mg} \mathrm{dm}^{-3}$ sulfur (ammonium sulfate PA), $300 \mathrm{mg}$ $\mathrm{dm}^{-3}$ phosphorus (monoammonium phosphate - MAP), $1.5 \mathrm{mg} \mathrm{dm}^{-3}$ copper (copper sulfate PA), $0.5 \mathrm{mg} \mathrm{dm}^{-3}$ boron (boric acid PA) and $5.0 \mathrm{mg} \mathrm{dm}^{-3}$ zinc (zinc sulfate PA). For nitrogen, two topdressing fertilizations were applied, adding $110 \mathrm{mg} \mathrm{dm}^{-3}$ urea to each experimental unit 30 and 60 days after the seedling emergence through the use of a nutrient solution (CARLOS et al., 2014).

The seeds were scarified in the opposite region to the hilum according to Santos et al. (2011), acquired through the Xingu Seed Network. Subsequently, two seeds were placed per pot, containing $3.5 \mathrm{dm}^{3}$ of soil. Thinning was carried out at 21 days after the seedling emergence, leaving one plant per pot. Irrigation was maintained until $60 \%$ of the field capacity by calculating the "void index" (INTERNATIONAL ASSOCIATION FOR ENGINEERING GEOLOGY, 1979).Naturally the pots were closed at the bottom, since it influences the replacement of soil moisture and, consequently, the leaching of the $\mathrm{K}^{+}$ion.

The morphological variables were measured monthly at plant height $(\mathrm{H}-\mathrm{cm})$, measured with the aid of a millimeter ruler, stem diameter (D - mm), determined with a digital caliper, number of leaves (NF) and number of internodes (NE). These data allowed the calculation of the relationship between height/diameter (H/D).

The gas exchanges of Hymenaea stigonocarpa seedlings were determined in the second fully expanded leaf pair to record the stomatal conductance. $\left[g_{s^{\prime}} \mathrm{mol}\left(\mathrm{H}_{2} \mathrm{O}\right)\right.$ $\left.\mathrm{m}^{-2} \mathrm{~s}^{-1}\right]$, net photosynthetic rate $\left[A, \mu \mathrm{mol}\left(\mathrm{CO}_{2}\right) \mathrm{m}^{-2} \mathrm{~s}^{-1}\right]$, transpiratory rate $[E, \mathrm{mmol}$ $\left(\mathrm{H}_{2} \mathrm{O}\right) \mathrm{m}^{-2} \mathrm{~s}^{-1}$, the relationship between internal and external $\mathrm{CO}_{2}$ concentrations ( $\mathrm{Ci}$ / $\mathrm{Ca}$ ) and the relationship between photosynthesis and internal $\mathrm{CO}_{2}$ concentrations ( $\mathrm{A} /$ Ci). Chlorophyll a fluorescence variables were not acclimated to the dark evaluated in the same leaf region as the gas exchange measurements, comprising electron carrier rate $\left(E T R, \mu m o l ~ m^{-2} \mathrm{~s}^{-1}\right)$, photochemical dissipation ( $\left.\mathrm{PP}\right)$, non-photochemical quenching (NPQ) and the effective quantum yield of the photo system II (Fv'/Fm'). These evaluations were carried out using a portable infrared LI-6400XTR gas analyzer (IRGA) (LI-COR, Lincoln, Nebraska, USA) between 08 AM and 11 AM, 250 days after planting. 
Chlorophyll indices (a and b) were evaluated using a CFL1030 Clorofilog equipment (Falker Agricultural Automation, Porto Alegre, BR) in the same leaves in which physiological measurements were performed. Total chlorophylls and the chlorophyll a/b ratios were calculated after determining the chlorophyll indices.

After eight months of experimentation, the seedlings were removed from the pots, separated in leaves, stems and roots, washed with distilled water and dried in an air circulation with average temperature at $65^{\circ} \mathrm{C}$ and $70^{\circ} \mathrm{C}$ deviation until reaching constant weight. After drying, the material was weighed and the dry leaf mass (DLM), dry stem mass (DSM) and dry root mass (DRM) were calculated, followed by total dry mass (TDM) and dry aerial portion mass (DAPM). The Dickson Quality Index (IQD) was calculated using biomass and growth data (DICKSON; LEAF; HOSNER, 1960). Prior to drying, leaf area (LA $-\mathrm{cm}^{2}$ ) was calculated using the Image J software by obtaining the digital image of the sheet. The specific leaf area (SLA $-\mathrm{cm}^{2} \mathrm{~g}^{-1}$ ) was then determined using the leaf area and dry leaf mass data.

To quantify the potassium content in seedling leaves, stems and roots, plant material was ground using a Willey mill and calcined in a muffle. The potassium determinations were carried out through flame emission photometry (EMBRAPA, 2009) extracted through dry digestion using the reagent nitric acid $\left(\mathrm{HNO}_{3}\right)$ and sodium hydroxide $(\mathrm{NaOH})$. Potassium content data were multiplied by biomass values to obtain the nutritional content accumulation values for each organ. The nutritional efficiency of $\mathrm{K}$ was evaluated by calculating the values of the efficiency of absorption $\left(\mathrm{AE}-\mathrm{mg} \mathrm{g}^{-1}\right)$, translocation (TE - \%) and utilization (UE - $\left.\mathrm{g}^{2} \mathrm{mg}^{-1}\right)$, calculated according to the equations described by Tomaz et al. (2009).

The data were subjected to an analysis of variance (ANOVA) at a significance level of $5 \%$, checked for their homogeneity and normality of errors (Levene and Shapiro Wilk test). A regression analysis was employed when a significant effect or model (1st and 2nd degrees) adjustment was observed, using the SISVAR 5.3 software. The software used to run Pearson's correlation coefficient was BIOESTAT. 


\section{RESULTS AND DISCUSSION}

A significant effect was observed for the following gas exchange variables: $g s, A$, $E, C i / C a$ and $A / C_{r}$ at $150 ; 129.75 ; 139 ; 112.5$ and $166.66 \mathrm{mg} \mathrm{dm}^{-3}$, respectively, which fit the quadratic model.The fluorescence parameters for chlorophylla, qP (0.39), NPQ (2.66) and $\mathrm{Fv}^{\prime} / \mathrm{Fm}^{\prime}(0.62)$ were not affected by potassium fertilization, except for ETR, with the highest estimated value of $96.29 \mu \mathrm{mol} \mathrm{m}^{-2} \mathrm{~s}^{-1}$ at $149,71 \mathrm{mg} \mathrm{dm}^{-3}$, with a quadratic adjustment (Figure 1). Regarding the assessed pigments, they did not differ and did not fit the mathematical models with mean values of 30.27 for chlorophyll a; 10.53 chlorophyll b; 40.80 total chlorophyll and 4.10 chlorophyll a/b ratio.

The increased gas exchange and chlorophyll fluorescence variables indicate that the aforementioned doses lead to greater use of photochemical/biochemical energy destined to metabolic processes during $\mathrm{CO}_{2}$ fixation, as these were directed to the photosystem (ETR) and Calvin cycle activity ( $A$ and gs), leading to higher ATP, NADPH, ADP and NADP rates (PIMENTEL, 2011).

Usually, plants submitted to potassium doses are quite sensitive to physiological factors (ZORB; SENBAYRAM; PEITER, 2014), although this does not mean that they will necessarily be influenced by potassium fertilization. In addition, this also depends on the plant characteristics, as certain species may respond positively or negatively to potassium fertilization, such as Houttuynia cordata Thunb. (XU et al., 2011) and Ginkgo biloba L. (GUO et al., 2016).

A strong relationship between photosynthesis rates and increased potassium fertilization levels was observed herein. This indicates that the assessed species displays a positive response to potassium, consistent with the proposed aim of the study. These results confirm the action of potassium in controlling stomatal opening and closing (HASANUZZAMAN et al., 2018) in Hymenaea stigonocarpa. 
Figure 1 - (a) Photosynthetic rate $(A)$, (b) stomatal conductance $\left(g_{s}\right)$, (c) relationship between internal and external $\mathrm{CO}_{2}$ concentrations $(\mathrm{Ci} / \mathrm{Ca})$, (d) ratio between photosynthesis and internal $\mathrm{CO}_{2}$ concentration $(\mathrm{A} / \mathrm{Ci})$, (e) transpiratory rate $(E)$ and (f) electron transport rate (ETR) of Hymenaea. Stigonocarpa (Fabaceae) seedlings submitted to different potassium doses

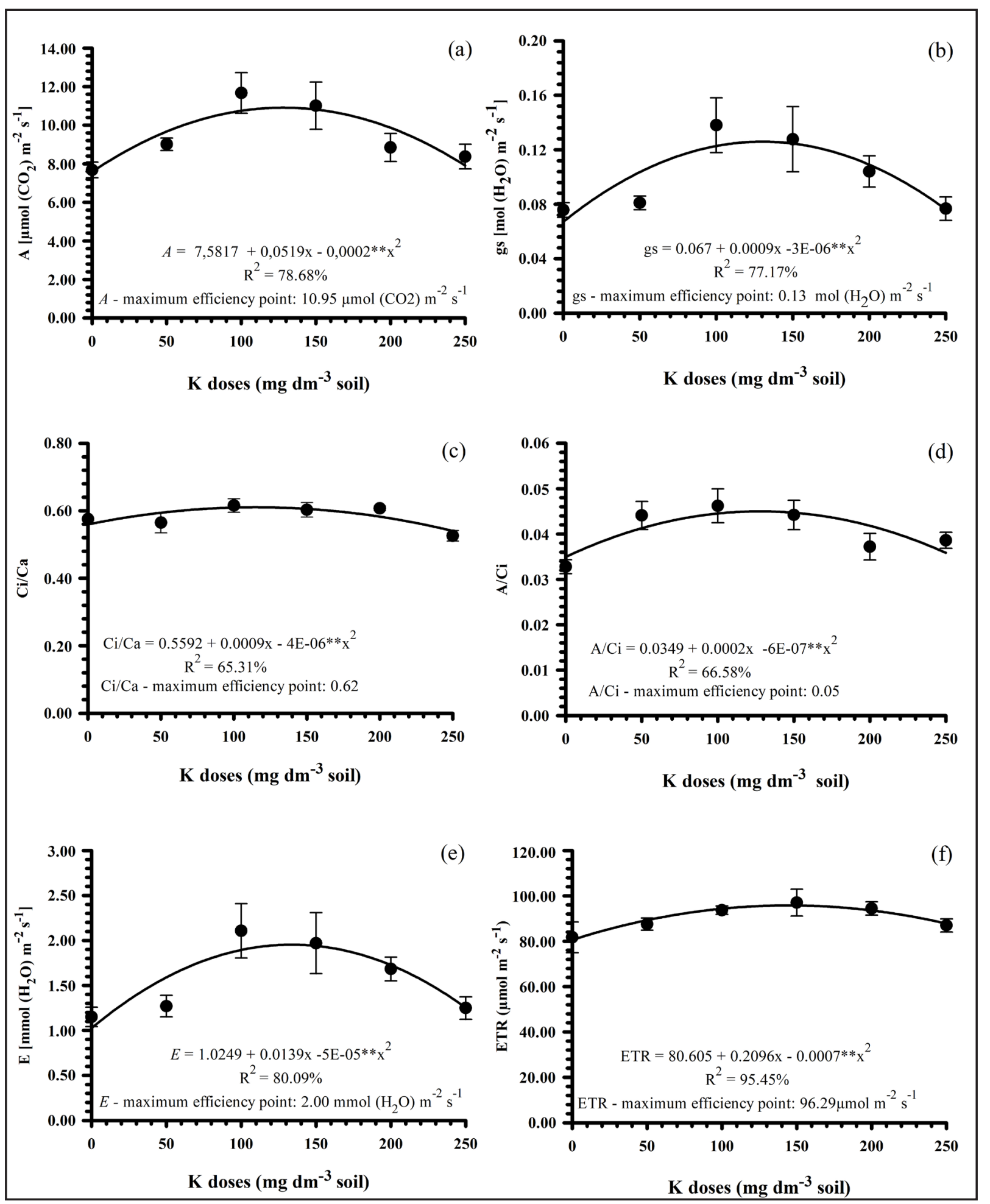

Source: Authors (2021) 
Since a direct relationship is noted between $g s, A$ and $E$, these variables were positively related to the increased ratio between internal and external $\mathrm{CO}_{2}$ concentration ( $\mathrm{Ci} / \mathrm{Ca}$ ) in the substomatic chamber of Hymenaea stigonocarpa seedlings. This is why it is important to define the optimal dose for each species, as potassium seedling deficiency or excess can restrict growth, resulting in an ionic damage to the plant and the soil itself, due to the saline effect of $\mathrm{KCl}$ on the root system, consequently generating diffusive or biochemical limitations due to the high mobility of $\mathrm{K}^{+}$cations and $\mathrm{Cl}^{-}$anions (MEURER, 2006).

General average, for the variables in which the treatments did not promote influence, as the number of leaves was 6.67, internode numbers 6.75, branch numbers 4.89, dry shoot mass $6.14 \mathrm{~g} \mathrm{plant}^{-1}$, dry leaf mass 4.29 g plant $^{-1}$; drystem mass $1.57 \mathrm{~g}$ plant $^{-1}$; dry root mass $16.09 \mathrm{~g} \mathrm{plant}^{-1}$ and total dry mass $23.03 \mathrm{~g}$ plant $^{-1}$, height/diameter ratio 5.36, root/shoot ratio 3.32, leaf area $456.53 \mathrm{~cm}^{2}$, specific leaf area $140.37 \mathrm{~cm}^{2} / \mathrm{g}$ and Dickson quality index 9.38, were not significantly affected. The highest height and diameter were obtained at potassium doses of 93 and 132.5 $\mathrm{mg} \mathrm{dm}^{-3}$, with estimated values of $28.22 \mathrm{~cm}$ and $5.51 \mathrm{~mm}$, respectively, adjusted to the quadratic model (Figure 2).

Figure 2 - (a) Height and (b) stem diameter of Hymenaea stigonocarpa (Fabaceae) seedlings as a function of potassium rates

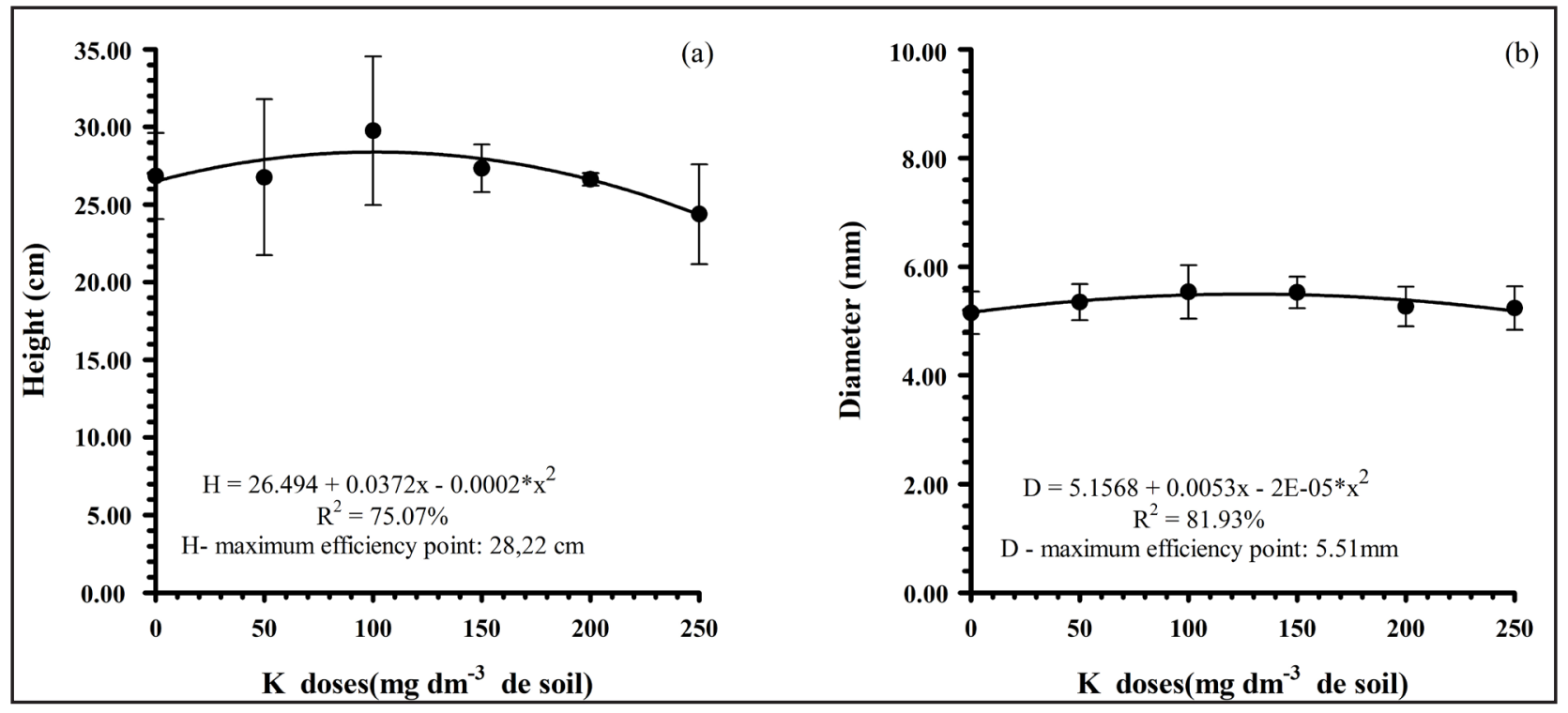

Source: Authors (2021) 
Hymenaea stigonocarpa seedling responses to potassium fertilization in relation to growth were influenced by physiological variables. Similar results have been reported by Maggard et al. (2016) and Battie-Laclau et al. (2016) for yellow pine (Pinus taeda L.) and eucalyptus (Eucalyptus grandis W. Hill ex Maiden) seedlings, respectively, indicating that the behavior of some forest species present higher nutritional demands in terms of potassium, in order to significantly increase both biometric and physiological parameters.

Itwas proven herein that potassium fertilization leads to increased photosynthetic activity and seedling height and diameter, even with no biomass increases. This response is due to the fact that potassium also promoted cell turgidity and elongation stimulated by the activation of numerous enzymes involved in the biochemical and physiological processes that influence plant growth and metabolism (HAFSI; DEBEZ; ABDELLY, 2014), where growth but no biomass accumulation may be observed.

Potassium doses adjusted to the quadratic and linear models only for leaf (19.04 $\mathrm{g} \mathrm{kg}^{-1}$ ) and stem $\left(10.89 \mathrm{~g} \mathrm{~kg}^{-1}\right) \mathrm{K}$ contents at 164.5 and $250 \mathrm{mg}$. K by dm${ }^{-3}$, respectively (Figure 3). No difference was observed regarding $\mathrm{K}$ root contents $\left(11.76 \mathrm{~g} \mathrm{~kg}^{-1}\right)$, and, as occurred with potassium accumulation, no difference and no adjustment for this variable were noticed. The highest estimated averages were $5.71 \mathrm{mg} \mathrm{plant}^{-1}$ in leaves, $1.15 \mathrm{mg}$ plant $^{-1}$ in stems and $9.07 \mathrm{mg} \mathrm{plant}^{-1}$ in roots.

Figure 3 - Potassium content of (a) leaves and (b) stems of Hymenaea stigonocarpa (Fabaceae) seedlings as a function of potassium doses

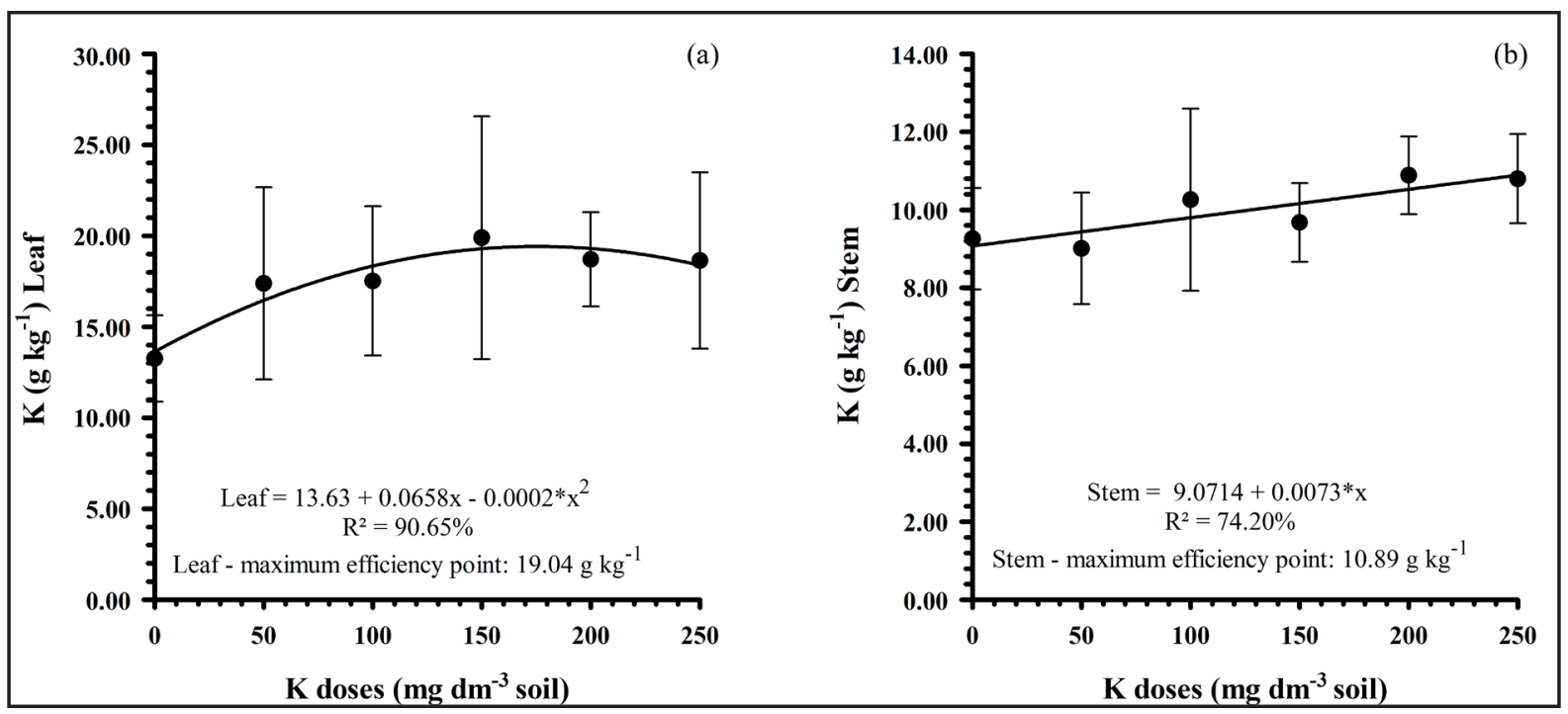

Source: Authors (2021) 
The previously results indicate the mobilization and redistribution effects of $\mathrm{K}$ in plants (SINGH; REDDY, 2017). This has been predicted for potassium, which is thought to be a high tissue mobility nutrient. Since plants absorb higher amounts of potassium than they really need, this does not necessarily mean that they will use it efficiently (VIEIRA; WEBER; SCARAMUZZA, 2015). This allows for greater $\mathrm{K}$ translocation to the vacuole, resulting in a concentration effect, which was confirmed herein through increasing $\mathrm{K}$ contents, although no increase in dry mass seedling production was noticed (MAIA et al., 2005).

In addition, excess $\mathrm{K}$ may cause nutritional imbalances and inhibit the absorption of other cations due to competition for exchange sites (SILVA; TREVIZAM, 2015). High doses of potassium chloride $(\mathrm{KCl})$ can also be detrimental and affect the seedling growth and quality due to chloride toxicity (SCHOSSLER et al., 2012).

The absorption efficiency and use of $\mathrm{K}$ showed linear and quadratic adjustment in the doses $250 \mathrm{mg} \mathrm{dm}^{-3}$ and $77.25 \mathrm{~g} \mathrm{~m}^{-3}$ of $\mathrm{K}$, obtained at the maximum point predicted by the curve of $3.12 \mathrm{mg} \mathrm{g}^{-1}$ and $16.99 \mathrm{~g}^{2} \mathrm{mg}^{-1}$, respectively (Figure 4). For the translocation efficiency, $\mathrm{K}$ doses did not promote a difference presenting an overall average of $73.53 \%$.

Figure 4 - (a) Absorption efficiency and (b) utilization efficiency f potassium of Hymenaea stigonocarpa (Fabaceae) seedlings as a function of potassium doses

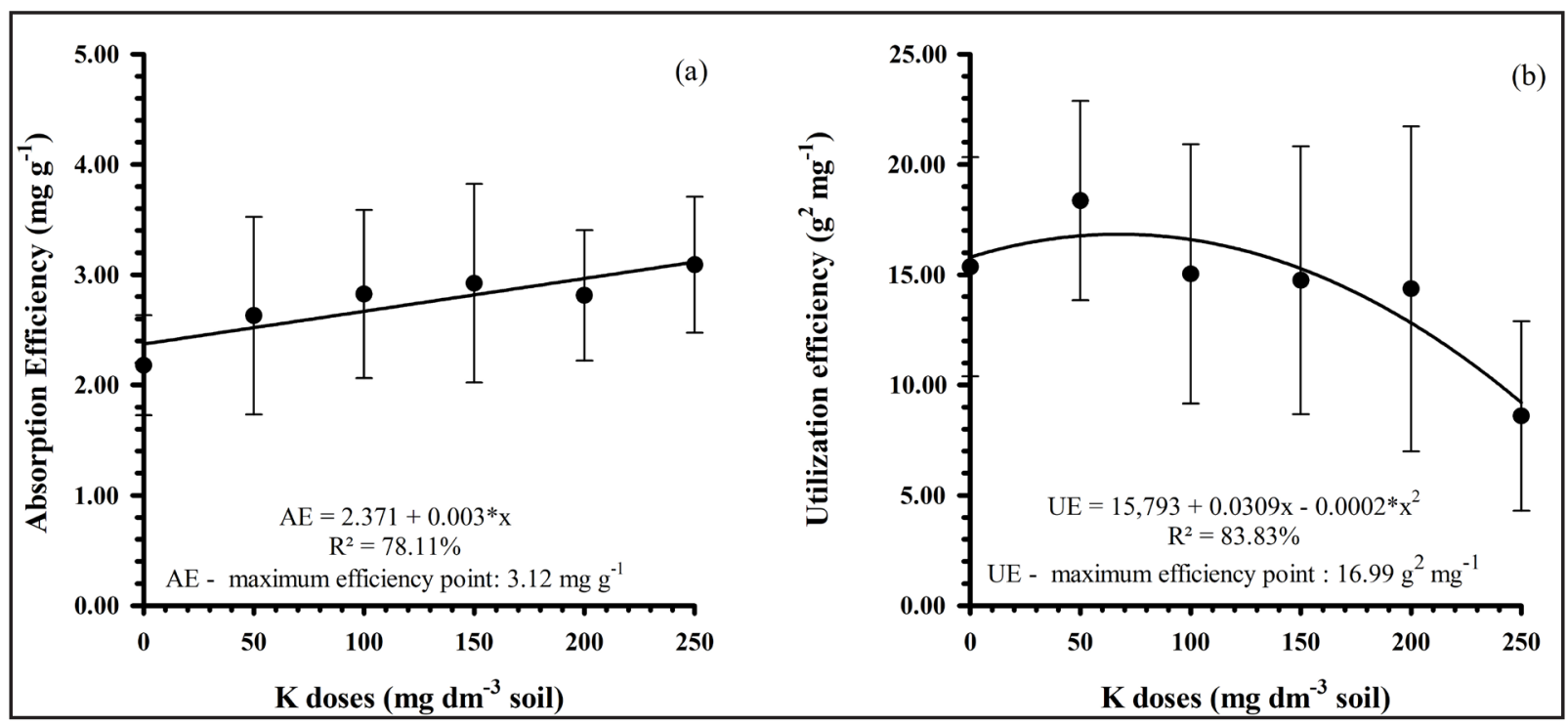

Source: Authors (2021) 
In terms of the correlation of the $H$. stigonocarpa seedling variables, height was positively correlated only with the ratio between internal and external $\mathrm{CO}_{2}$ concentration. The diameter, on the other hand, proved to be strongly correlated to physiological variables, such as photosynthetic rate, stomatal conductance, transpiratory rate and electron transport rate. There was also a correlation between the physiological variables among themselves, such as the photosynthetic rate with stomatal conductance, ratio between photosynthetic rate and internal $\mathrm{CO}_{2}$ concentration, electron transport rate. As well as, the stomatal conductance with the ratio of internal and external concentration of $\mathrm{CO}_{2}$, transpiratory rate and electron transport rate. The electron transport rate was positively correlated with the $\mathrm{K}$ content in the leaf, while the $\mathrm{K}$ content in the leaf was correlated with the $\mathrm{K}$ absorption efficiency (Table 2).

Table 2 - Pearson's linear correlation coefficient of variables among seedlings. Hymenaea stigonocarpa Mart ex Hayne (Fabaceae) as a function of potassium doses

\begin{tabular}{|c|c|c|c|c|c|c|c|c|c|c|c|c|}
\hline & D & $A$ & $g_{s}$ & $\mathrm{Ci} / \mathrm{Ca}$ & $\mathrm{A} / \mathrm{Ci}$ & $E$ & ETR & TF & TC & $\mathrm{AE}$ & TE & UE \\
\hline $\mathrm{H}$ & $0.68^{\text {ns }}$ & $0.75^{\mathrm{ns}}$ & $0.77^{\mathrm{ns}}$ & $0.83 *$ & $0.53^{\text {ns }}$ & $0.73^{\text {ns }}$ & $0.42^{\text {ns }}$ & $-0.1^{\mathrm{ns}}$ & $-0.2^{\mathrm{ns}}$ & $-0.1^{\mathrm{ns}}$ & $0.54^{\mathrm{ns}}$ & $0.58^{\mathrm{ns}}$ \\
\hline D & & $0.98 *$ & $0.88 *$ & $0.53^{\text {ns }}$ & $0.77^{\mathrm{ns}}$ & $0.87 *$ & $0.78 *$ & $0.57^{\mathrm{ns}}$ & $-0.1^{\mathrm{ns}}$ & $0.46^{\mathrm{ns}}$ & $0.21^{\mathrm{ns}}$ & $0.24^{\mathrm{ns}}$ \\
\hline A & & & $0.95 *$ & $0.62^{\text {ns }}$ & $0.80 *$ & $0.93 *$ & $0.78 *$ & $0.52^{\text {ns }}$ & $0.19^{\mathrm{ns}}$ & $0.44^{\mathrm{ns}}$ & $0.25^{\mathrm{ns}}$ & $0.19^{n s}$ \\
\hline$g_{s}$ & & & & $0.77 *$ & $0.69^{n s}$ & $0.98 *$ & 0.80 * & $0.43^{\text {ns }}$ & $0.18^{n s}$ & $0.36^{\mathrm{ns}}$ & $0.24^{\mathrm{ns}}$ & $0.12^{\mathrm{ns}}$ \\
\hline $\mathrm{Ci} / \mathrm{Ca}$ & & & & & $0.37^{\mathrm{ns}}$ & $0.79 *$ & $0.63^{n s}$ & $0.07^{\mathrm{ns}}$ & $0.08^{\mathrm{ns}}$ & $-0.1^{\mathrm{ns}}$ & $0.58^{\text {ns }}$ & $0.44^{\text {ns }}$ \\
\hline $\mathrm{A} / \mathrm{Ci}$ & & & & & & $0.74^{\text {ns }}$ & $0.65^{\mathrm{ns}}$ & $0.58^{\mathrm{ns}}$ & $0.40^{\mathrm{ns}}$ & $0.65^{\mathrm{ns}}$ & $0.48^{\text {ns }}$ & $-0.0^{\text {ns }}$ \\
\hline$E$ & & & & & & & $0.89 *$ & $0.54^{\mathrm{ns}}$ & $0.28^{\mathrm{ns}}$ & $0.44^{\mathrm{ns}}$ & $0.35^{\mathrm{ns}}$ & $0.11^{\mathrm{ns}}$ \\
\hline ETR & & & & & & & & 0.81 * & $0.38^{\mathrm{ns}}$ & $0.63^{\mathrm{ns}}$ & $0.33^{\text {ns }}$ & $0.04^{\mathrm{ns}}$ \\
\hline TF & & & & & & & & & $0.49^{n s}$ & 0.91 * & $0.05^{\mathrm{ns}}$ & $-0.2^{\text {ns }}$ \\
\hline TC & & & & & & & & & & $0.66^{\mathrm{ns}}$ & $0.14^{\mathrm{ns}}$ & $-0.7^{n s}$ \\
\hline$A E$ & & & & & & & & & & & $-0.0^{\mathrm{ns}}$ & $-0.5^{\text {ns }}$ \\
\hline ET & & & & & & & & & & & & $0.52^{\mathrm{ns}}$ \\
\hline
\end{tabular}

Source: Authors (2021)

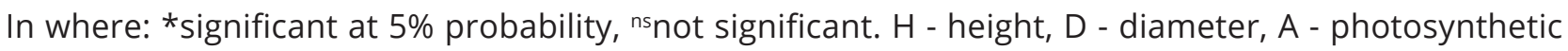
rate, gs - stomatal conductance, $\mathrm{Ci} / \mathrm{Ca}$ - ratio between internal and external $\mathrm{CO}_{2}$ concentration, $\mathrm{A} /$ $\mathrm{Ci}$ - ratio between photosynthetic rate and internal $\mathrm{CO}_{2}$ concentration, E - transpiratory rate, ETR electron transport rate, TF - K content in the leaf, TC - content in the stem K, AE - absorption efficiency $\mathrm{K}$, TE - translocation efficiency $\mathrm{K}$ and UE - utilization efficiency $\mathrm{K}$. 
Physiologically, the efficiency of absorption, transport and use of $\mathrm{K}$, allowed the translocation of photosynthetic assimilates, a source for carbon and nitrogen metabolism to occur (TOMAZ et al., 2009). In view of this, there was an increase in the efficiency of absorption and use of $K$, transferred to the vacuole accumulated in the aerial part. This better photosynthetic performance was able to increase the growth parameters, even under toxic $\mathrm{Cl}^{-}$concentrations.

\section{CONCLUSIONS}

Potassium fertilization leads to morphological, physiological and potassium content changes in Hymenaea stigonocarpa Mart. ex Hayne seedlings. In general, potassium affected stomatal opening, transpiration and gas exchange through the osmotic adjustment effect, leading to maximum increases in stem height and diameter, which in turn lead to a concentration effect concerning $\mathrm{K}$ contents. Therefore, the most adequate $\mathrm{K}$ doses are recommended from 150 to $200 \mathrm{mg} \mathrm{dm}^{-3}$ during the cultivation phase.

\section{ACKNOWLEDGEMENTS}

The authors would like to thank CAPES and FAPEG for the granted scholarships, the Postgraduate Program in Agrarian Sciences (Department of Agronomy) and Goiano Federal Institute - Rio Verde Campus.

\section{REFERENCES}

BATTIE-LACLAU, P. et al. Effects of potassium and sodium supply on drought-adaptive mechanisms in Eucalyptus grandis plantations. New phytologist, Cambridge, v. 203, n. 2, p. 401-413, abr. 2014.

BATTIE-LACLAU, P. I. et al. Potassium fertilization increases water-use efficiency for stem biomass production without affecting intrinsic water-use efficiency in Eucalyptus grandis plantations. Forest Ecology and Management, Amsterdam, v. 364, n. 1, p. 77-89, mar. 2016. 
CARLOS, L. et al. Growth and mineral nutrition in Annona crassiflora Mart. seedlings subjected to nutrient deprivation. Australian Journal of Basic and Applied Sciences, [s. I.],v. 8, n. 13, p. 379-384, jan. 2014.

COSTA, A. C. et al. The effect of irradiance and water restriction on photosynthesis in young jatobá-do-Cerrado (Hymenaea stigonocarpa) plants. Photosynthetica, Prague, v. 53, n. 1, p. 1-10, mar. 2015.

DICKSON, A.; LEAF, A. L.; HOSNER, J. F. Quality appraisal of white spruce and white pine seedling stock in nurseries. Forest Chronicle, [s. I.],v. 36, n. 1, p. 10-13, 1960.

EMBRAPA. Manual de análises químicas de solos, plantas e fertilizantes. 2. ed. Brasília, DF: Embrapa Informação Tecnológica, 2009. 627 p.

GOMES, L.; MIRANDA. H. S.; BUSTAMANTE, M. M. C. How can we advance the knowledge on the behavior and effects of fire in the Cerrado biome? Forest Ecology and Management, Amsterdam, v. 417, p. 281-290, maio 2018.

GRANATO-SOUZA, D.; BARBOSA, A. C. M. C.; CHAVES, H. F. Drivers of growth variability of Hymenaea stigonocarpa, a widely distributed tree species in the Brazilian Cerrado. Dendrochronologia, [s. I.],v. 53, n. 1, p. 73-81, fev. 2019.

GUO, J. et al. The Effects of Fertilization on the Growth and Physiological Characteristics of Ginkgo biloba L. Forests, [s. I.],v. 7, n. 12, p. 1-14, nov. 2016.

HAFSI, C.; DEBEZ, A.; ABDELLY, C. Potassium deficiency in plants: effects and signaling cascades. Acta Physiologiae Plantarum, [s. I.],v. 36, n. 5, p. 055-1070, jan. 2014.

HASANUZZAMAN, M. et al. Potassium: a vital regulator of plant responses and tolerance to abiotic stresses. Agronomy, [s. I.], v. 8, n. 3, p. 1-29, mar. 2018.

INTERNATIONAL ASSOCIATION FOR ENGINEERING GEOLOGY. Classification of rocks and soils for engineering geological mapping: part I: rock and soil materials. Bulletin of the International Association of Engineering Geology, Paris, v. 19, n. 1, p. 355-371, 1979.

MAGGARD, A. O. et al. Fertilization reduced stomatal conductance but not photosynthesis of Pinus taeda which compensated for lower water availability in regards to growth. Forest Ecology and Management, Amsterdam, v. 381, n. 1, p. 37-47, dez. 2016.

MAIA, C. E. et al. Teores foliares de nutrientes em meloeiro irrigado com águas de diferentes salinidades. Revista Brasileira de Engenharia Agrícola e Ambiental, Campina Grande, n. 9, supl., p. 292-295, jan. 2005.

MEURER, E. J. Potássio. In: FERNANDES, M. S. (ed.). Nutrição mineral de plantas. Viçosa, MG: Sociedade Brasileira de Ciência do Solo, 2006. p. 281-298.

OLIVEIRA, S. R. et al. Are protected areas effective in preserving anurans and promoting biodiversity discoveries in the Brazilian Cerrado? Journal of Nature Conservation, [s. I.], v. 52, n. 125734, p. 1-5, ago. 2019. 
PIMENTEL, C. Metabolismo de carbono de plantas cultivadas e o aumento de $\mathrm{CO}_{2}$ e de $\mathrm{O}_{3}$ atmosférico: situação e previsões. Bragantia, Campinas, v. 70, n. 1, p.1-12, maio 2011.

RAlJ, B. V. Avaliação da fertilidade do solo. Piracicaba: Associação Brasileira para Pesquisa da Potassa e do Fosfato, 1981. 142 p.

SANTOS, L. C. R. et al. Ambientes protegidos e substratos com doses de composto orgânico comercial e solo na formação de mudas de Jatobazeiro em Aquidauana-MS. Engenharia Agrícola, Jaboticabal, v. 31, n. 2, p. 249-259, abr. 2011.

SCHOSSLER, T. R. et al. Salinidade: efeitos na fisiologia e na nutrição mineral de plantas. Enciclopédia Biosfera, Goiânia, v. 8, n. 15, p. 1564-1578, nov. 2012.

SILVA, C. R.; SOUZA, K. B.; FURTADO, W. F. Evaluation of the Progress of Intensive Agriculture in the Cerrado Piauiense - Brazil. Procedia, [s. I.], v. 5, n. 13, p. 51-58, jan. 2013.

SILVA, M. L. S.; TREVIZAM, A. R. Interações iônicas e seus efeitos na nutrição das plantas. Informações Agronômicas, Peachtree Corners, n. 149, p. 10-16, 2015.

SILVA, P. O. et al. Physiological and morphological behavior of Hymenaea stigonocarpa seedlings submitted to phosphorus. Floresta e Ambiente, Rio de Janeiro, v. 27, n. 1, p. 1-9, abr. 2020.

SINGH, S. K.; REDDY, V. R. Potassium Starvation Limits Soybean Growth More than the Photosynthetic Processes across $\mathrm{CO}_{2}$ Levels. Frontiers in Plant Science, [s. I.], v. 8, n. 991, p. 1-16, jul. 2017.

TAIZ, L.; ZEIGER, E. Fisiologia vegetal. 6. ed. Porto Alegre: Artmed, 2017. 888 p.

TOMAZ, M. A. et al. Eficiência relacionada à absorção e utilização de nitrogênio, fósforo e enxofre, em plantas de cafeeiros enxertadas, cultivadas em vasos. Ciência e Agrotecnologia, Lavras, v. 33, n. 4, p. 993-1001, ago. 2009.

VIEIRA, C. R.; WEBER, O. L. S.; SCARAMUZZA, J. F. Efeitos da saturação por bases no crescimento e na nutrição de mudas de jatobá. Revista de Ciências Ambientais, Canoas, v. 9, n. 1, p. 7-17, jul. 2015.

$\mathrm{XU}, \mathrm{Y} . \mathrm{W}$. et al. Optimization of potassium for proper growth and physiological response of Houttuynia cordata Thunb. Environmental and Experimental Botany, Elmsford, v. 71, n. 2, p. 292-297, jun. 2011.

ZAHOOR, R. et al. Potassium application regulates nitrogen metabolism and osmotic adjustment in cotton (Gossypium hirsutum L.) functional leaf under drought stress. Journal of Plant Physiology, Stuttgart, v. 215, n. 1, p. 30-38, maio 2017.

ZORB, C.; SENBAYRAM, M.; PEITER, E. Potassium in agriculture: Status and perspectives. Journal of Plant Physiology, Stuttgart, v. 171, n. 9, p. 656-669, maio 2014. 


\section{Authorship Contribution}

\section{1 - Andréia Mendes da Costa}

Agricultural Engineer, Dr.

https://orcid.org/0000-0003-0395-6190• andreiamendes226@gmail.com

Contribution: Conceptualization, Data curation, Formal Analysis, Investigation, Methodology, Project administration, Visualization, Writing - original draft, Writing review \& editing

\section{2 - Leandro Carlos}

Forestry Engineer, Dr., Professor

https://orcid.org/0000-0003-1736-6079• leandro.carlos@ifgoiano.edu.br

Contribution: Conceptualization, Methodology, Supervision, Writing - review \& editing

\section{3 - Patrícia Oliveira da Silva}

Biologist, Dr.

https://orcid.org/0000-0003-2242-320X•patriciasilvaifgoiano@gmail.com

Contribution: Conceptualization, Investigation, Methodology, Writing - review \& editing

\section{4 - Paulo Eduardo Menezes-Silva}

Biologist, Dr.

https://orcid.org/0000-0002-8122-3489• paulomenezesbio@gmail.com

Contribution: Investigation

\section{5 - José Milton Alves}

Agronomist, Dr.

https://orcid.org/0000-0002-2477-206X•jmiltonalves@gmail.com

Contribution: Resources

\section{6 - Thomas Jefferson Cavalcante}

Agricultural Engineer, MSc.

https://orcid.org/0000-0003-0332-2390 •tjc_net@hotmail.com

Contribution: Investigation 


\section{7 - Jorciane Souza Dias}

Environmental Engineer

https://orcid.org/0000-0001-8412-4737•jorciane_souza@hotmail.com

Contribution: Investigation

\section{How to quote this article}

Costa, A. M.; Carlos, L.; Silva, P. O.; Menezes-Silva, P. E.; Alves, J. M.; Cavalcante, T. J.; Dias, J. S. Morphophysiological responses of Hymenaea stigonocarpa Mart. ex Hayne seedlings submitted to potassium fertilization. Ciência Florestal, Santa Maria, v. 31, n. 3, p. 1427-1443, 2021. DOI 10.5902/1980509842754. Available from: https://doi.org/10.5902/1980509842754. Accessed: xx abbreviated-month. 2021. 